medRxiv preprint doi: https://doi.org/10.1101/2021.06.11.21258759; this version posted June 16, 2021. The copyright holder for this preprint (which was not certified by peer review) is the author/funder, who has granted medRxiv a license to display the preprint in perpetuity.

All rights reserved. No reuse allowed without permission.

\title{
Evidence for lower threshold for diagnosis of hypertension: inferences from an urban-slum cohort in
}

\section{India}

Onkar Awadhiya ${ }^{1}$, Ankit Tiwari ${ }^{1}$, Premlata Solanki ${ }^{1}$, Anuja Lahiri $^{2}$, Neelesh Shrivastava ${ }^{1}$, Ankur Joshi $^{2}$, Abhijit P Pakhare ${ }^{2}$, Rajnish Joshi ${ }^{15}$

\section{Affiliations and Institutions}

\begin{tabular}{|l|l|l|l|}
\hline No & Name & Affiliation & Email \\
\hline 1 & Onkar & $\begin{array}{l}\text { Department of Medicine, All India } \\
\text { Institute of Medical Sciences, } \\
\text { Bhopal }\end{array}$ & onkarawadhiya@gmail.com \\
\hline 1 & Ankit Tiwari & $\begin{array}{l}\text { Department of Medicine, All India } \\
\text { Institute of Medical Sciences, } \\
\text { Bhopal }\end{array}$ & ankitinvincible21@gmail.com \\
\hline 1 & $\begin{array}{l}\text { Premlata } \\
\text { Solanki }\end{array}$ & $\begin{array}{l}\text { Department of Medicine, All India } \\
\text { Institute of Medical Sciences, } \\
\text { Bhopal }\end{array}$ & solankilata89@gmail.com \\
\hline 2 & Anuja Lahiri & $\begin{array}{l}\text { Department of Community and } \\
\text { Family Medicine, All India Institute } \\
\text { of Medical Sciences, Bhopal }\end{array}$ & anuja.ds@aiimsbhopal.edu.in \\
\hline 2 & $\begin{array}{l}\text { Neelesh } \\
\text { Shrivastava }\end{array}$ & $\begin{array}{l}\text { NCD Urban Project, Department of } \\
\text { Medicine, All India Institute of } \\
\text { Medical Sciences, Bhopal }\end{array}$ & neeleshstv@gmail.com \\
\hline 2 & Ankur Joshi & $\begin{array}{l}\text { Department of Community and } \\
\text { Family Medicine, All India Institute } \\
\text { of Medical Sciences, Bhopal }\end{array}$ & ankur.cfm@aiimsbhopal.edu.in \\
\hline 2 & $\begin{array}{l}\text { Abhijit P } \\
\text { Pakhare }\end{array}$ & $\begin{array}{l}\text { Family Medicine, All India Institute } \\
\text { of Medical Sciences, Bhopal }\end{array}$ & $\begin{array}{l}\text { abhijit.cfm@aiimsbhopal.edu.in } \\
\text { Institute of Medical Sciences, } \\
\text { Bhopal }\end{array}$ \\
\hline Rajnish Joshi & $\begin{array}{l}\text { Department of Medicine, All India } \\
\text { rajnish.genmed@aiimsbhopal.edu.in }\end{array}$ & and \\
\hline
\end{tabular}

\section{Author Email}

\$Corresponding Author-

Dr Rajnish Joshi

Department of Medicine, All India Institute of Medical Sciences, Bhopal

Email-rajnish.genmed@aiimsbhopal.edu.in

\section{Word Count-}

Abstract- 285

Main Text- 2597

No. of Tables- 3

No. of Figures- 2

NOTE: This preprint reports new research that has not been certified by peer review and should not be used to guide clinical practice. 
medRxiv preprint doi: https://doi.org/10.1101/2021.06.11.21258759; this version posted June 16, 2021. The copyright holder for this preprint (which was not certified by peer review) is the author/funder, who has granted medRxiv a license to display the preprint in perpetuity.

All rights reserved. No reuse allowed without permission.

\section{Evidence for lower threshold for diagnosis of hypertension: inferences from an urban-slum cohort in} India

\section{Abstract \\ Background}

Hypertension (HTN) is a key risk-factor for cardiovascular diseases (CVDs). Blood-pressure (BP) categorizations between systolic blood pressure (SBP) of 120 and 140 remain debatable. In the current study we aim to evaluate if individuals with a baseline SBP between 130-140 mm Hg (hypertension as per AHA 2017 guidelines) have a significantly higher proportion of incident hypertension on follow-up, as compared to those with SBP between $120-130 \mathrm{~mm} \mathrm{Hg}$.

\section{Methods}

Secondary data analysis was performed in a community-based cohort, instituted, and followed since 2017. Participants were aged $\geq 30$ years, residents of urban slums in Bhopal. BP was measured at or near home by Community Health Workers (CHWs). Two-year follow up was completed in 2019. We excluded participants who were on BP reduction therapy, had fewer than two out-of-office BP measurements and who could not be followed. Eligible participants were re-classified based on baseline BP in four categories: Normal (Category-A), Elevated-BP (Category-B), Variable-BP (Category-C) and reclassified HTN based on AHA-2017 (Category-D). Proportion of individuals who developed incident hypertension on follow up was primary outcome.

\section{Result}

Out of 2649 records, 768 (28.9\%), 647 (24.4\%), 586 (22.1\%), 648 (24.4\%) belonged to Categories A, B, C and D respectively. Incident HTN with cut-off of $140 / 90 \mathrm{~mm} \mathrm{Hg}$ was, $1.6 \%, 2.6 \%, 6.7 \%, 12 \%$ in categories $A, B, C$ and $D$ respectively. Incidence of incident hypertension in individuals with a baseline SBP between 130-140 $\mathrm{mm} \mathrm{Hg}$ (Category D) was significantly higher as compared to those with SBP between $120-130 \mathrm{~mm} \mathrm{Hg}$ (Category B).

\section{Conclusion}

We conclude that biological basis for AHA-2017 definition of hypertension is relatively robust also for low income and resource-limited settings. Evidence from our longitudinal study will be useful for policy makers for harmonizing national guidelines with AHA-2017.

Keywords- hypertension, elevated blood pressure, community health worker, cardiovascular diseases 
medRxiv preprint doi: https://doi.org/10.1101/2021.06.11.21258759; this version posted June 16, 2021. The copyright holder for this preprint (which was not certified by peer review) is the author/funder, who has granted medRxiv a license to display the preprint in perpetuity.

All rights reserved. No reuse allowed without permission.

\section{Evidence for lower threshold for diagnosis of hypertension: inferences from an urban-slum cohort in}

\section{India}

\section{Introduction}

Cardiovascular disorders (CVD) are the leading cause of morbidity and mortality worldwide. ${ }^{1}$ Hypertension is the most powerful, independent, preventable risk factor for death and disability from cardiovascular diseases. ${ }^{2}$ It is also a leading risk factor for all-cause mortality and the largest contributor to global disability-adjusted life years (DALYs). ${ }^{3} T$ he current prevalence of hypertension (based on the $\geq 140 / 90 \mathrm{mmHg}$ threshold) in India is estimated to be $28.9 \%$ in both men and women. ${ }^{4}$ Higher a blood-pressure (BP) value greater is cardiovascular risk. Starting at 115/75 mmHg, CVD risk doubles with each increment of $20 / 10 \mathrm{mmHg}$ throughout the blood pressure range. Risk of CV death increases twofold if $\mathrm{BP}$ rises to $135 / 85$, fourfold if $\mathrm{BP}$ rises to $155 / 95$, and eightfold at $175 / 105$. $^{5,6}$

While BP measurement technology is simple and is widely available, its diagnostic cut-offs and accuracy of measurement have been a matter of debate. ${ }^{7,8}$ Final results of SPRINT Study have reaffirmed systolic blood pressure of $120 \mathrm{~mm} \mathrm{Hg}$ as a target to treat, ${ }^{9}$ further $10 \mathrm{~mm} \mathrm{Hg}$ lower than AHA/ACC 2017 guidelines. ${ }^{10}$ Lowering of diagnostic threshold would increase prevalence of hypertension, and will pose a higher burden on provision of pharmacotherapy. ${ }^{11,12}$ About a third of SPRINT study participants had their Systolic BP below $132 \mathrm{~mm} \mathrm{hg}$, between 132-145mm Hg and above $145 \mathrm{~mm} \mathrm{Hg}$ respectively, and those in the lowest tertile had greatest benefit by intensive treatment [HR $0.70(95 \% \mathrm{Cl} 0.51-0.95)] .{ }^{13}$ In SPRINT study, BP was measured by automated oscillometric measurement, which minimizes the effect of white coat hypertension, unlike blood-pressure measured in most clinical practice settings. ${ }^{14}$

While SPRINT demonstrated lowering of BP control threshold, and its consequent pharmacotherapy to be beneficial, it was achieved in a setting of more accurate BP-measurement. This study prompted AHA/ACC in 2017 to lower the diagnostic threshold from previous 140/90 to 130/80mm Hg. ${ }^{10}$ In 2018, European guidelines revised its guidelines, and elaborated on thresholds based on measurement technique. ${ }^{15}$ These guidelines have caused uncertainty in diagnosis of hypertension. An individual with a systolic BP (SBP) between 120 and $140 \mathrm{~mm} \mathrm{Hg}$ or diastolic BP (DBP between 80 and $89 \mathrm{~mm}$ $\mathrm{Hg}$ ) may have either true hypertension or a white-coat hypertension or no-hypertension, depending on measurement technique or guideline applied for decision-making. ${ }^{16}$ It has been demonstrated that as many as $70 \%$ of all white-coat hypertension, and $95 \%$ of masked hypertension falls between this systolic blood pressure-range. ${ }^{17} \mathrm{Arguments}$ for clinical benefit of a lower blood-pressure threshold are early recognition of disease and mortality benefit, with an implicit assumption that if untreated, BP of these individuals will continue to rise. ${ }^{18}$

National guidelines in India have not yet adopted AHA 2017 guidelines for hypertension, and it has been debated that addition of more individuals with newer definitions will overwhelm our Public health delivery 
medRxiv preprint doi: https://doi.org/10.1101/2021.06.11.21258759; this version posted June 16, 2021. The copyright holder for this preprint (which was not certified by peer review) is the author/funder, who has granted medRxiv a license to display the preprint in perpetuity.

All rights reserved. No reuse allowed without permission.

system. ${ }^{19,20}$ Lack of longitudinal studies and potential misclassification in blood-pressure values at lower diagnostic cut-offs were identified as concerns. ${ }^{21}$

We had established a population based cohort in 2017, to evaluate CVD risk-factors and their control. ${ }^{22}$ Community health workers (CHWs) obtained multiple sets of BP measurements and all therapeutic decisions were based on diagnostic threshold of SBP $>/=140$ or DBP $>/=90$ at baseline, which remains the current national guideline. If AHA/ACC 2017 guidelines are applied, individuals with BP below this threshold would get re-classified as having elevated blood-pressure (SBP between 120 and $130 \mathrm{~mm} \mathrm{Hg}$ ) or hypertension (SBP between 130 and $140 \mathrm{~mm} \mathrm{Hg}$ ). We completed a two-year follow up of cohort in $2019,{ }^{23}$ and a secondary data analysis will enable us to evaluate blood-pressure outcomes in re-classified cohort members. Our key research question is, among cohort members with at least two out-of-office BP assessments at baseline, do individuals with SBP values between 130 and 140, (as compared to those with SBP between 120 and $130 \mathrm{~mm} \mathrm{Hg}$ ) have a significantly higher proportion of incident hypertension or mean SBP at the end of two years. Our hypothesis is that a robust classification system will exhibit a consistent trend in blood-pressure outcomes on follow up.

\section{Methods}

Design: The current study is a secondary data analysis from a community based cohort that was established in year 2017, and is being followed up thereafter. ${ }^{23}$ Primary study design was approved by institutional ethics committee, and participants who provided a written informed consent were included in the study. Setting: Cohort-members include consenting non-pregnant adults, aged 30 years or more, residing in 16different urban slums in city of Bhopal, India. At baseline in year 2017-18, eligible participants had their CVD-risk assessment done based on interview, anthropometry, and BP measurement. BP was measured on multiple occasions in all participants, which consisted of an average of three values obtained one minute apart, on each occasion. First set of blood-pressures were measured by $\mathrm{CHWs}$ at home of all the participants, second set was obtained by study supervisors in neighbourhood camps and a third set was obtained in public health facilities for confirmation of hypertension status. First two of these BPs were outof-office measurements. We completed a two-year follow up of all participants in 2019, and obtained oneset of home BP measurement for all participants and a confirmatory home BP measurement for those with newly detected hypertension above $140 / 90 \mathrm{~mm} \mathrm{Hg}$. All BP measurements were obtained using a digital sphygmomanometer (Omron digital apparatus model 7200, Kyoto, Japan).

Data source: The data of the primary study was collected using a Commcare based mobile application, and is stored in cloud based secure servers. A dataset, stripped of all personal identifiers and consisting of required variables was extracted for the current study. This data-set contains information on a total of 6174 individuals, and includes variables pertaining to demography (age, gender, education, wealth index 
medRxiv preprint doi: https://doi.org/10.1101/2021.06.11.21258759; this version posted June 16, 2021. The copyright holder for this preprint (which was not certified by peer review) is the author/funder, who has granted medRxiv a license to display the preprint in perpetuity.

All rights reserved. No reuse allowed without permission.

classification), blood-pressure values obtained at different time-points, and CVD-risk assessment at baseline (tobacco use, physical activity status, prior CVD history, waist circumference, body mass index). The data-set also contains information about initiation of anti-hypertensive pharmacotherapy, linkage to facilities, adherence and monitoring of those on therapy.

Procedures and definitions: We identified those individuals who had their BP measured at-least twice at baseline in 2017. It was required that BP on both occasions at baseline was obtained in out-of-office setting, in order to be comparable to follow-up measurements obtained in 2019 , which were all home based. Hence, Individuals who had one out-of-office and one facility level BP measurement at baseline, and those who did not have a follow up value were excluded. We also excluded individuals who were advised any pharmacological or non-pharmacological measures for blood-pressure reduction. Thus, individuals who had two BP values above therapeutic threshold of 140/90 $\mathrm{mm} \mathrm{Hg}$ at baseline or those on a BP-lowering medication for alternate indication (such as for ischemic heart disease, ischemic stroke, diabetes nephropathy) were excluded. Thus, data-set for the current study consisted of adults above age of 30years, who were therapy naïve, and had multiple comparable out-of-office BP values at baseline and on follow-up.

We used baseline out-of-office BP values and re-classified individuals into four different bloodpressure categories, Normal (Category A), Elevated blood pressure based on AHA 2017 (Category B), Variable blood pressure (Category C) and reclassified hypertension based on AHA 2017 (Category D). (Table 1) Our primary outcome was proportion of incident hypertension (SBP $>/=140 \mathrm{~mm} \mathrm{Hg}$ or DBP $>/=90 \mathrm{~mm}$ $\mathrm{Hg}$ ) . We used this definition, as all individuals in our data-set had their BPs below this threshold at baseline. Hypertension as per AHA 2017 definition (SBP $>/=130 \mathrm{~mm} \mathrm{Hg}$ or DBP $>/=80 \mathrm{~mm} \mathrm{Hg}$ ) and mean SBP were our secondary outcomes.

Statistical analysis: Our primary outcome was proportion of individuals who developed incident hypertension on follow up. Our key comparison was between categories $B, C$ and $D$, with category $A$ as a reference. We also performed a descriptive analysis, comparing CVD-risk factors amongst individuals in each category, and used appropriate tools for data visualization. We used chi-square test to compare nominal variables, One way ANOVA or Kruskal Wallis test followed by post-hoc pair wise comparisons for numerical variables. $p$-value of less than 0.05 was considered as statistical significant. Analyses were conducted using the R Statistical language (version 4.0.3; R Core Team, 2020) on macOS Catalina 10.15.6, using the packages gtsummary (version 1.4.1; Daniel Sjoberg et al., 2021), ${ }^{24}$ ggforce (version 0.3.2; Thomas Lin Pedersen, 2020) ${ }^{25}$ and tidyverse (version 1.3.0; Wickham et al., 2019). ${ }^{26}$ 
medRxiv preprint doi: https://doi.org/10.1101/2021.06.11.21258759; this version posted June 16, 2021. The copyright holder for this preprint (which was not certified by peer review) is the author/funder, who has granted medRxiv a license to display the preprint in perpetuity.

All rights reserved. No reuse allowed without permission.

\section{Results}

Of a total of 2649 records who met the study criteria, $648(24.4 \%)$ individuals had BP above the AHA 2017 defined threshold of 130/80mm Hg at baseline, and were labelled as 're-classified HTN'(category D). Another 647 (24.4\%) individuals had 'elevated BP' (category B), and 586 (22.1\%) had a 'variable' BP between these two groups (category C). Remaining 768 (28.9\%) individuals had a normal BP (Category A). Individuals in highest BP-category (Category D) were older (median age 42 years), had a higher proportion of men (47\%), had more tobacco-users (38\%), higher prevalence of dysglycemia (23\%) or abdominal obesity (62\%). These CVD-risk factors (higher age, male-gender, tobacco-use, dysglycemia, obesity) demonstrated a rising trend across BP-categories. (Table 2)

Outcomes were also significantly different across BP-categories. Proportion of individuals who developed incident hypertension with a diagnostic threshold of $140 / 90 \mathrm{~mm} \mathrm{Hg}$ was $1.6 \%, 2.6 \%, 6.7 \%$, $12 \%$ and in categories $A, B, C$ and $D$ respectively. Proportion of individuals with incident hypertension were higher in each-category with a lower diagnostic threshold of 130/80 mm Hg. The trend of higher incidenthypertension across BP-categories persisted with lower diagnostic threshold. (Table 3)

Over a two-year period BP-categorization was unchanged in 1068 (40.3\%) individuals. Those in categories $A$ and $D$ (normal and re-classified HTN) were most stable as $68 \%$ and $62 \%$ of them were in the same BP-category on follow-up. BP-categorization was dynamic in categories B and C (elevated and variable BP) as only 145 (11.8\%) individuals were in the same BP-category on follow-up. (Figure 1)

\section{Discussion}

We found that BP-categorization as per AHA 2017 is robust, as individuals re-classified as having HTN based on diagnostic threshold of $130 / 80 \mathrm{~mm} \mathrm{Hg}$ not only have a higher prevalence of CVD-risk factors at baseline, are also more likely to develop incident HTN. Previously entire $20 \mathrm{~mm} \mathrm{Hg}$ spectrum of SBP between 120-139 was categorized as 'pre-hypertension' which was subdivided into two $10 \mathrm{~mm} \mathrm{Hg}$ bands of elevated-BP (SBP between 120-129) and stage I hypertension (SBP between 130-139) as per AHA 2017 classification. We found that difference in outcomes in these $10 \mathrm{mmHg}$ bands are large, as only $2.6 \%$ Individuals with 'elevated-BP' developed HTN (above 140/90mm Hg) as compared to $12 \%$ in those with reclassified stage I hypertension.

In our study BP-levels were measured by $\mathrm{CHWs}$ using digital sphygmomanometers. Accuracy in BP measurement has been a concern when we attempt to classify individuals in narrow $10 \mathrm{~mm} \mathrm{Hg}$ bands. It is known that office-BP measurement has its inaccuracies, ${ }^{8}$ and out-of-office BP is better as it would reduce white-coat hypertension. ${ }^{27}$ However inter-instrument variability has been a concern for home-BP measurements. ${ }^{28}$ We used an intermediate strategy, wherein BP is measured using same instrument by community-health workers (CHWs) at or near the home of the participants. While accuracy of such 
medRxiv preprint doi: https://doi.org/10.1101/2021.06.11.21258759; this version posted June 16, 2021. The copyright holder for this preprint (which was not certified by peer review) is the author/funder, who has granted medRxiv a license to display the preprint in perpetuity.

All rights reserved. No reuse allowed without permission.

measurements in comparison to 24-hour ambulatory blood pressure measurement (ABPM) is not established, observed differences in our study even in narrow $10 \mathrm{~mm} \mathrm{Hg}$ bands validates these measurements.

We encountered BP-variability in about one-fifth of our participants at baseline. These were individuals who had their SBP between 120-129 mm Hg on one occasion, and between 130-139 mm Hg on another. One explanation of this variability is location of BP-measurements as one was a home-based measurement and another was obtained in the neighborhood. Proportion of individuals with a variable BP was low on follow-up as all measurements were obtained at home.(figure 1) BP is a dynamic physiological parameter which is affected by various factors like volume status, cardiac functions, emotional state, sleepawake status, time of the day, season or the age of the person. ${ }^{29} \mathrm{High} \mathrm{BP}$ variability has gained attention as an independent CVD risk factor. ${ }^{30}$ While we currently believe that two BP-values need to be concordant for a more robust diagnosis of hypertension, diagnostically uncertain variable individuals however are a special phenotype. ${ }^{31}$ In our study distribution of other CVD risk-factors as well as progression to incident HTN in individuals with a variable BP was intermediate to those with 'elevated-BP' or those with 're-classified HTN'. This finding also strengthens the concept that long-term variability is a biological characteristic rather than a measurement error. It however remains debatable if benefits of anti-hypertensive treatment should be extended to this group as well. ${ }^{32}$

Purpose of revision of diagnostic threshold has been to identify a minimum level which is associated with adverse impact on the bodily functions, target organ damage and increased mortality and at which any intervention to treat is likely to be associated with reduction of its ill effects. In 2017 AHA released new guidelines for the prevention, detection, evaluation and management of hypertension which used systolic BP of $130 \mathrm{mmHg}$ or higher and diastolic BP of $80 \mathrm{mmHg}$ or higher to classify individuals as hypertensive. While JNC-7 guidelines which were in common use since 2003 used systolic BP of $140 \mathrm{mmHg}$ or higher and diastolic BP of $90 \mathrm{mmHg}$ or higher for the same.Measurement of blood pressure in entire communities helps determine burden of disease, which is expected to become higher with reduced diagnostic thresholds. In present study, about a quarter of individuals who were previously classified as 'not having hypertension' as per JNC-guidelines, satisfied revised AHA 2017 criteria to be re-classified as hypertension. In a previous study, with a diagnostic threshold of $140 / 90 \mathrm{~mm} \mathrm{Hg}$, we estimated that $25 \%$ of adults have hypertension. ${ }^{33}$ This proportion would become about $44 \%$ with a lower threshold of $130 / 80 \mathrm{~mm} \mathrm{Hg}$. This increment is similar as in other settings, and lowering of threshold also increases the absolute number of individuals with blood-pressure unawareness, and those with white-coat hypertension. ${ }^{34-36}$ This would increase the burden on health-systems, and push for lowering of BP-control closer to therapeutic threshold of $120 / 80 \mathrm{~mm} \mathrm{Hg}$. (Figure 2) While, this is challenging but need to harmonize various hypertension guidelines to a diagnostic and therapeutic threshold of $130 / 80 \mathrm{~mm} \mathrm{Hg}$ is unavoidable. ${ }^{37}$ 
medRxiv preprint doi: https://doi.org/10.1101/2021.06.11.21258759; this version posted June 16, 2021. The copyright holder for this preprint (which was not certified by peer review) is the author/funder, who has granted medRxiv a license to display the preprint in perpetuity.

All rights reserved. No reuse allowed without permission.

Our study has several limitations. First, only two out-of-office BP measurements were available, and presence of a third similarly obtained value would have reduced the proportion of those with a variable BP. Thus, we might have overestimated the proportions of individuals with a 'variable BP' $^{\prime}$ at baseline. Second, a complete set of BP values was available in only about two-fifths of the entire cohort. Thus, our inferences are generalizable only to population sub-groups that are adherent to follow-ups and repeat BP measurements. Third, rise in blood-pressure is only an intermediate outcome and our study was not designed to evaluate hard-CVD outcomes such as target organ damage or mortality. Despite these limitations, a key strength of the current study is using available cohort data from a low-income setting, where BP was measured with minimal sophistication, to demonstrate robustness of BP-categorizations below the diagnostic threshold of $140 / 90 \mathrm{~mm} \mathrm{Hg}$.

To conclude, biological basis for AHA 2017 definition of hypertension is reasonably strong, even in low-income settings where BP measurements are done with minimal resources. Individuals with elevated and variable BP are also distinguishable biological categories. The results of our study can be generalised to resource constrained conditions such as ours. Hence, use of a simple digital sphygmomanometer and application of lower threshold of BP cut-offs can be a more practical way to identify individuals with hypertension unawareness, higher likelihood of incident hypertension and individuals with variable BP. With demonstration of mortality-benefit of treating individuals with lower SBP as demonstrated in SPRINT study, there is a need to apply these concepts for better patient-care. Evidence from our longitudinal study will be useful for policy makers for harmonizing national guidelines with AHA 2017.

Funding- This study was funded by Indian Council of Medical Research, New Delhi as an extramural project grant. Funders have no role in data collection, analysis and writing of the manuscript. (Grant - PI- Dr Rajnish Joshi, IRIS-2014-0976)

Ethics approval- The study design was approved by the Institutional Human Ethics Committee of All India Institute of Medical Sciences, Bhopal (Ref: IHEC-LOP/2017/EF00045).

Informed consent- Participant Information Sheet in Hindi language was provided to each participant. All participants provided written informed consent prior to initiation of any study procedures.

Data Statement- Raw data of this study is not deposited in any public repository. However, anonymized raw data of this study would be available to academicians or researchers on reasonable request to corresponding author.

Author contributions: RJ conceived the study; APP, AT, PS and OA developed the protocol; ALand NS acquired data, AJ, APP and RJ supervised data acquisition, APP, OA and RJ analyzed data and wrote first draft. All authors critically reviewed the first draft and provided inputs for its revisions. 
medRxiv preprint doi: https://doi.org/10.1101/2021.06.11.21258759; this version posted June 16, 2021. The copyright holder for this preprint (which was not certified by peer review) is the author/funder, who has granted medRxiv a license to display the preprint in perpetuity.

\section{References:}

1. Roth GA, Huffman MD, Moran AE, Feigin V, Mensah GA, Naghavi M, et al. Global and Regional Patterns in Cardiovascular Mortality From 1990 to 2013. Circulation [Internet]. 2015 Oct 27 [cited 2021 Jun 8];132(17):1667-78. Available from:

https://www.ahajournals.org/doi/full/10.1161/CIRCULATIONAHA.114.008720

2. Nag T, Ghosh A. Cardiovascular disease risk factors in Asian Indian population: A systematic review. J Cardiovasc Dis Res. 2013 Dec;4(4):222-8.

3. Mensah GA. Epidemiology and global burden of hypertension [Internet]. ESC CardioMed. Oxford University Press; [cited 2021 Jun 8]. Available from: https://oxfordmedicine.com/view/10.1093/med/9780198784906.001.0001/med-9780198784906chapter-61

4. Anchala R, Kannuri NK, Pant $\mathrm{H}$, Khan H, Franco OH, Di Angelantonio E, et al. Hypertension in India: a systematic review and meta-analysis of prevalence, awareness, and control of hypertension. J Hypertens. 2014 Jun;32(6):1170-7.

5. Lewington S, Clarke R, Qizilbash N, Peto R, Collins R, Prospective Studies Collaboration. Age-specific relevance of usual blood pressure to vascular mortality: a meta-analysis of individual data for one million adults in 61 prospective studies. Lancet Lond Engl. 2002 Dec 14;360(9349):1903-13.

6. Chobanian AV, Bakris GL, Black HR, Cushman WC, Green LA, Izzo JL, et al. Seventh report of the Joint National Committee on Prevention, Detection, Evaluation, and Treatment of High Blood Pressure. Hypertens Dallas Tex 1979. 2003 Dec;42(6):1206-52.

7. Chobanian AV. Hypertension in 2017-What Is the Right Target? JAMA. 2017 Feb 14;317(6):579-80.

8. Campbell PT, White WB. Utility of ambulatory blood pressure monitoring for the management of hypertension. Curr Opin Cardiol. 2017 Jul;32(4):365-72.

9. SPRINT Research Group, Lewis CE, Fine L, Beddhu S, Cheung AK, Cushman WC, et al. Final Report of a Trial of Intensive versus Standard Blood-Pressure Control. N Engl J Med. 2021 May 20;384(20):192130 .

10. Whelton PK, Carey RM, Aronow WS, Casey DE, Collins KJ, Dennison Himmelfarb C, et al. 2017 ACC/AHA/AAPA/ABC/ACPM/AGS/APhA/ASH/ASPC/NMA/PCNA Guideline for the Prevention, Detection, Evaluation, and Management of High Blood Pressure in Adults: Executive Summary: A Report of the American College of Cardiology/American Heart Association Task Force on Clinical Practice Guidelines. Hypertens Dallas Tex 1979. 2018 Jun;71(6):1269-324.

11. Cho SMJ, Lee H, Kim HC. Comparison and Implication of the Contemporary Blood Pressure Guidelines on Korean Population. Korean Circ J [Internet]. 2020 Feb 18 [cited 2021 Jun 8];50(6):485-98. Available from: https://www.ncbi.nlm.nih.gov/pmc/articles/PMC7234852/

12. Mirzaei M, Mirzaei M, Mirzaei M, Bagheri B. Changes in the prevalence of measures associated with hypertension among Iranian adults according to classification by ACC/AHA guideline 2017. BMC Cardiovasc Disord [Internet]. 2020 Aug 14 [cited 2021 Jun 8];20(1):372. Available from: https://doi.org/10.1186/s12872-020-01657-0 
medRxiv preprint doi: https://doi.org/10.1101/2021.06.11.21258759; this version posted June 16, 2021. The copyright holder for this preprint (which was not certified by peer review) is the author/funder, who has granted medRxiv a license to display the preprint in perpetuity.

All rights reserved. No reuse allowed without permission.

13. SPRINT Research Group, Wright JT, Williamson JD, Whelton PK, Snyder JK, Sink KM, et al. A Randomized Trial of Intensive versus Standard Blood-Pressure Control. N Engl J Med. 2015 Nov 26;373(22):2103-16.

14. Johnson KC, Whelton PK, Cushman WC, Cutler JA, Evans GW, Snyder JK, et al. Blood Pressure Measurement in SPRINT (Systolic Blood Pressure Intervention Trial). Hypertens Dallas Tex 1979. 2018 May;71(5):848-57.

15. Williams B, Mancia G, Spiering W, Agabiti Rosei E, Azizi M, Burnier M, et al. 2018 ESC/ESH Guidelines for the management of arterial hypertension: The Task Force for the management of arterial hypertension of the European Society of Cardiology (ESC) and the European Society of Hypertension (ESH). Eur Heart J [Internet]. 2018 Sep 1 [cited 2021 Jun 8];39(33):3021-104. Available from: https://doi.org/10.1093/eurheartj/ehy339

16. Bell K, Doust J, McGeechan K, Horvath AR, Barratt A, Hayen A, et al. The potential for overdiagnosis and underdiagnosis because of blood pressure variability: a comparison of the 2017 ACC/AHA, 2018 ESC/ESH and 2019 NICE hypertension guidelines. J Hypertens [Internet]. 2021 Feb [cited 2021 Jun 8];39(2):236-42. Available from: https://www.ncbi.nlm.nih.gov/pmc/articles/PMC7810411/

17. Kim B-K, Rhee M-Y. Impact of 2018 ESC/ESH and 2017 ACC/AHA Hypertension Guidelines: Difference in Prevalence of White-Coat and Masked Hypertension. Healthc Basel Switz. 2020 May 3;8(2).

18. Unger T, Borghi C, Charchar F, Khan NA, Poulter NR, Prabhakaran D, et al. 2020 International Society of Hypertension Global Hypertension Practice Guidelines. Hypertension [Internet]. 2020 Jun 1 [cited 2021 Jun 8];75(6):1334-57. Available from: https://www.ahajournals.org/doi/10.1161/HYPERTENSIONAHA.120.15026

19. Narang. Implications of 2017 hypertension guidelines for Indian patients [Internet]. [cited 2021 Jun 8 ]. Available from: https://www.j-pcs.org/article.asp?issn=2395-

5414; year=2018; volume=4; issue $=1 ;$ spage $=3$; epage $=5$; aulast $=$ Narang

20. Agarwal A, Huffman MD, Reddy KS, Prabhakaran D. The 2017 American College of Cardiology/ American Heart Association Clinical Practice Guideline for Blood Pressure: Implications for India. Natl Med J India. 2018 Jun;31(3):129-32.

21. Gupta K, Ramakrishnan S, Zachariah G, Rao JS, Mohanan PP, Venugopal K, et al. Impact of the 2017 ACC/AHA guidelines on the prevalence of hypertension among Indian adults: Results from a crosssectional survey. Int J Cardiol Hypertens [Internet]. 2020 Dec 1 [cited 2021 Jun 8]; 7:100055. Available from: https://www.sciencedirect.com/science/article/pii/S259008622030032X

22. Pakhare A, Joshi A, Khadanga S, Kumar S, Atal S, Ingle V, et al. Feasibility of Community Health Worker based cardiovascular risk reduction strategies in urban slums of Bhopal: Rationale, design and baseline results of community based study. medRxiv [Internet]. 2020 Sep 18 [cited 2021 Jun 8];2020.09.18.20189639. Available from: https://www.medrxiv.org/content/10.1101/2020.09.18.20189639v1

23. Pakhare AP, Lahiri A, Shrivastava N, Joshi A, Khadanga S, Joshi R. Incident hypertension in urban slums of central India: a prospective cohort study. Open Heart [Internet]. 2021 Jan [cited 2021 Jun 8];8(1):e001539. Available from: https://openheart.bmj.com/lookup/doi/10.1136/openhrt-2020001539

24. Presentation-Ready Data Summary and Analytic Result Tables [Internet]. [cited 2021 Jun 8]. Available from: http://www.danieldsjoberg.com/gtsummary/ 
medRxiv preprint doi: https://doi.org/10.1101/2021.06.11.21258759; this version posted June 16, 2021. The copyright holder for this preprint (which was not certified by peer review) is the author/funder, who has granted medRxiv a license to display the preprint in perpetuity. All rights reserved. No reuse allowed without permission.

25. Pedersen TL. Accelerating "ggplot2" [R package ggforce version 0.3.3] [Internet]. Comprehensive $\mathrm{R}$ Archive Network (CRAN); 2021 [cited 2021 Jun 8]. Available from: https://CRAN.Rproject.org/package=ggforce

26. Wickham H, Averick M, Bryan J, Chang W, McGowan LD, François R, et al. Welcome to the Tidyverse. J Open Source Softw [Internet]. 2019 Nov 21 [cited 2021 Jun 8];4(43):1686. Available from: https://joss.theoj.org/papers/10.21105/joss.01686

27. Krakoff LR. Blood Pressure Out of the Office: Its Time Has Finally Come. Am J Hypertens [Internet]. 2016 Mar 1 [cited 2021 Jun 8];29(3):289-95. Available from: https://doi.org/10.1093/ajh/hpv179

28. on behalf of the HOPE Asia Network, Park S, Buranakitjaroen P, Chen C-H, Chia Y-C, Divinagracia R, et al. Expert panel consensus recommendations for home blood pressure monitoring in Asia: the Hope Asia Network. J Hum Hypertens [Internet]. 2018 Apr [cited 2021 Jun 8];32(4):249-58. Available from: http://www.nature.com/articles/s41371-017-0025-y

29. Chadachan VM, Ye MT, Tay JC, Subramaniam K, Setia S. Understanding short-term blood-pressurevariability phenotypes: from concept to clinical practice. Int J Gen Med [Internet]. 2018 Jun 22 [cited 2021 Jun 8];11:241-54. Available from: https://www.ncbi.nlm.nih.gov/pmc/articles/PMC6018855/

30. Stevens SL, Wood S, Koshiaris C, Law K, Glasziou P, Stevens RJ, et al. Blood pressure variability and cardiovascular disease: systematic review and meta-analysis. BMJ [Internet]. 2016 Aug 9 [cited 2021 Jun 8];354:i4098. Available from: https://www.bmj.com/content/354/bmj.i4098

31. Kerr EA, Zikmund-Fisher BJ, Klamerus ML, Subramanian U, Hogan MM, Hofer TP. The Role of Clinical Uncertainty in Treatment Decisions for Diabetic Patients with Uncontrolled Blood Pressure. Ann Intern Med [Internet]. 2008 May 20 [cited 2021 Jun 8];148(10):717-27. Available from: https://www.acpjournals.org/doi/full/10.7326/0003-4819-148-10-200805200-00004

32. Assessment and management of blood-pressure variability | Nature Reviews Cardiology [Internet]. [cited 2021 Jun 8]. Available from: https://www.nature.com/articles/nrcardio.2013.1

33. Pakhare AP, Lahiri A, Shrivastava N, Krishna NS, Joshi A, Atal S, et al. Risk factors of uncontrolled hypertension in urban slums of Central India : A Community health worker based two-year follow up. medRxiv [Internet]. 2021 Feb 5 [cited 2021 Jun 8];2021.02.02.21251036. Available from: https://www.medrxiv.org/content/10.1101/2021.02.02.21251036v1 (Preprint)

34. Choi W-J, Lee H-S, Hong JH, Chang H-J, Lee J-W. Comparison of the JNC7 and 2017 American College of Cardiology/American Heart Association Guidelines for the Management of Hypertension in Koreans: Analysis of Two Independent Nationwide Population-Based Studies. Int J Environ Res Public Health [Internet]. 2019 Dec [cited 2021 Jun 8];16(24). Available from:

https://www.ncbi.nlm.nih.gov/pmc/articles/PMC6950121/

35. Poudel B, Booth JNI, Sakhuja S, Moran AE, Schwartz JE, Lloyd-Jones DM, et al. Prevalence of ambulatory blood pressure phenotypes using the 2017 American College of Cardiology/American Heart Association blood pressure guideline thresholds: data from the Coronary Artery Risk Development in Young Adults study. J Hypertens [Internet]. 2019 Jul [cited 2021 Jun 8];37(7):140110. Available from:

https://journals.Iww.com/jhypertension/Abstract/2019/07000/Prevalence_of_ambulatory_blood_pr essure_phenotypes.13.aspx

36. Abariga SA, Khachan H, Al Kibria GM. Prevalence and Determinants of Hypertension in India Based on the 2017 ACC/AHA Guideline: Evidence from the India National Family Health Survey. Am J Hypertens 
medRxiv preprint doi: https://doi.org/10.1101/2021.06.11.21258759; this version posted June 16, 2021. The copyright holder for this preprint (which was not certified by peer review) is the author/funder, who has granted medRxiv a license to display the preprint in perpetuity.

All rights reserved. No reuse allowed without permission.

[Internet]. 2020 Mar 13 [cited 2021 Jun 8];33(3):252-60. Available from: https://doi.org/10.1093/ajh/hpz181

37. Antza C, Doundoulakis I, Stabouli S, Kotsis V. American, European and international hypertension guidelines: Time to shake hands? Int J Cardiol Hypertens [Internet]. 2020 Dec 17 [cited 2021 Jun 8];8. Available from: https://www.ncbi.nlm.nih.gov/pmc/articles/PMC7803036/ 
medRxiv preprint doi: https://doi.org/10.1101/2021.06.11.21258759; this version posted June 16, 2021. The copyright holder for this preprint (which was not certified by peer review) is the author/funder, who has granted medRxiv a license to display the preprint in perpetuity.

All rights reserved. No reuse allowed without permission.

Table 1: Blood-pressure categories and their definitions in the current study

\begin{tabular}{|c|c|c|c|}
\hline \multirow[t]{2}{*}{ Category } & \multirow[t]{2}{*}{ Name } & \multicolumn{2}{|c|}{ Definition } \\
\hline & & Systolic Blood pressure & $\begin{array}{l}\text { Diastolic Blood } \\
\text { Pressure }\end{array}$ \\
\hline$A$ & Normal & $\begin{array}{l}\text { Less than } 120 \mathrm{~mm} \mathrm{Hg} \text { on } \\
\text { two occasions }\end{array}$ & $\begin{array}{l}\text { Less than } 80 \mathrm{~mm} \mathrm{Hg} \text { on } \\
\text { two occasions }\end{array}$ \\
\hline B & $\begin{array}{l}\text { Elevated BP } \\
\text { based on AHA/ACC definition* }\end{array}$ & $\begin{array}{l}120-129 \mathrm{~mm} \mathrm{Hg} \text { on two } \\
\text { occasions, or once in } \\
\text { this range and once } \\
\text { below } 120 \mathrm{~mm} \mathrm{Hg}\end{array}$ & $\begin{array}{l}\text { Less than } 80 \mathrm{~mm} \mathrm{Hg} \text { on } \\
\text { two occasions }\end{array}$ \\
\hline C & Variable BP & $\begin{array}{c}\text { Above } 130 \mathrm{~mm} \mathrm{Hg} \text { on } \\
\text { one occasion, and } \\
\text { between } 120-129 \mathrm{~mm} \\
\mathrm{Hg} \text { on another }\end{array}$ & $\begin{array}{c}\text { Between } 80-89 \mathrm{~mm} \mathrm{Hg} \\
\text { on one occasion, or less } \\
\text { than } 80 \mathrm{~mm} \text { Hg on two } \\
\text { occasions }\end{array}$ \\
\hline $\mathrm{D}$ & $\begin{array}{l}\text { Reclassified Hypertension } \\
\text { based on AHA/ACC definition* }\end{array}$ & $\begin{array}{l}130-139 \mathrm{~mm} \mathrm{Hg} \text { on two } \\
\text { occasions, or once in } \\
\text { this range and once } \\
140 \mathrm{~mm} \mathrm{Hg} \text { or more. }\end{array}$ & $\begin{array}{l}80-89 \mathrm{~mm} \mathrm{Hg} \text { on two } \\
\text { occasions, or once in } \\
\text { this range and once } \\
90 \mathrm{~mm} \mathrm{Hg} \text { or more. }\end{array}$ \\
\hline
\end{tabular}

* AHA/ACC definition as per reference (10) BP=Blood pressure 
medRxiv preprint doi: https://doi.org/10.1101/2021.06.11.21258759; this version posted June 16, 2021. The copyright holder for this preprint (which was not certified by peer review) is the author/funder, who has granted medRxiv a license to display the preprint in perpetuity.

All rights reserved. No reuse allowed without permission.

Table 2: Baseline and characteristics of the study population

\begin{tabular}{|c|c|c|c|c|c|c|}
\hline Characteristic & $\begin{array}{c}\text { Overall, } N= \\
2,649^{1}\end{array}$ & $\begin{array}{c}\text { Normal } \\
(\mathrm{SBP}<120), \\
N=768^{1}\end{array}$ & $\begin{array}{c}\text { Elevated } \\
\text { (SBP 120-129), } \\
\mathrm{N}=647^{1}\end{array}$ & $\begin{array}{l}\text { Variable, } \\
N=586^{1}\end{array}$ & $\begin{array}{c}\text { Reclassified HTN } \\
\text { (SBP 130-139) } \\
\mathrm{N}=648^{1}\end{array}$ & $\mathrm{p}$-value \\
\hline BP-category & & $A$ & B & C & $D$ & \\
\hline Median Age & $40(35,48)$ & $36(32,44)$ & $40(34,47)$ & $42(35,50)$ & $42(36,50)$ & $<0.001$ \\
\hline Male Gender & 957 (36\%) & $180(23 \%)$ & 247 (38\%) & $228(39 \%)$ & $302(47 \%)$ & $<0.001$ \\
\hline \multicolumn{7}{|l|}{ Wealth Tertile } \\
\hline $\mathrm{T} 1$ & $704(28 \%)$ & 215 (29\%) & $155(25 \%)$ & $153(27 \%)$ & $181(29 \%)$ & \\
\hline $\mathrm{T} 2$ & $823(32 \%)$ & $261(36 \%)$ & $213(34 \%)$ & $171(30 \%)$ & $178(29 \%)$ & 0.009 \\
\hline T3 & $1,015(40 \%)$ & $254(35 \%)$ & $254(41 \%)$ & 245 (43\%) & $262(42 \%)$ & \\
\hline Tobacco use & 868 (33\%) & $228(30 \%)$ & $201(31 \%)$ & 196 (33\%) & $243(38 \%)$ & 0.012 \\
\hline Dysglycemia & $451(17 \%)$ & $89(12 \%)$ & $113(17 \%)$ & $103(18 \%)$ & $146(23 \%)$ & $<0.001$ \\
\hline $\begin{array}{l}\text { Abdominal } \\
\text { Obesity }\end{array}$ & $1,351(51 \%)$ & $294(38 \%)$ & $339(52 \%)$ & $318(54 \%)$ & $400(62 \%)$ & $<0.001$ \\
\hline $\begin{array}{l}\text { Median Waist } \\
\text { circumference }\end{array}$ & $84(75,91)$ & $78(70,85)$ & $84(77,92)$ & $84(76,92)$ & $87(80,95)$ & $<0.001$ \\
\hline $\begin{array}{l}\text { Median Body } \\
\text { Mass Index }\end{array}$ & $23.3(20.3,26.2)$ & $\begin{array}{c}21.5(19.0 \\
24.6)\end{array}$ & $\begin{array}{c}23.6(20.8, \\
26.5)\end{array}$ & $\begin{array}{c}23.5(20.9 \\
26.4)\end{array}$ & $24.4(21.9,27.7)$ & $<0.001$ \\
\hline
\end{tabular}


medRxiv preprint doi: https://doi.org/10.1101/2021.06.11.21258759; this version posted June 16, 2021. The copyright holder for this preprint (which was not certified by peer review) is the author/funder, who has granted medRxiv a license to display the preprint in perpetuity.

All rights reserved. No reuse allowed without permission.

Table 3: Outcome measures in study population

\begin{tabular}{lccccc}
\hline & $\begin{array}{c}\text { Normal } \\
(\mathrm{SBP}<120), \\
\mathrm{N}=768^{1}\end{array}$ & $\begin{array}{c}\text { Elevated } \\
\text { SBP 120- } \\
129), \\
\mathrm{N}=647^{1}\end{array}$ & $\begin{array}{c}\text { Variable, } \\
\mathrm{N}=586^{1}\end{array}$ & $\begin{array}{c}\text { Reclassified } \\
\text { HTN } \\
\text { (SBP 130- } \\
139) \\
\mathrm{N}=648^{1}\end{array}$ & $\mathrm{p}^{- \text {value }^{2}}$ \\
\hline $\begin{array}{l}\text { BP-category } \\
\text { Mean Baseline SBP (SD) }\end{array}$ & $\mathrm{A}$ & $\mathrm{B}$ & $\mathrm{C}$ & $\mathrm{D}$ & \\
$\begin{array}{l}\text { Mean Follow-up SBP (SD) } \\
\begin{array}{l}\text { Incident Hypertension } \\
(>130 / 80 \text { mm Hg) }\end{array}\end{array}$ & $114.4(11.7)$ & $122.7(11.9)$ & $128.1(14.8)$ & $133.5(14.8)$ & $<0.001$ \\
$\begin{array}{l}\text { Incident Hypertension } \\
(>140 / 90 \mathrm{~mm} \mathrm{Hg})\end{array}$ & $12(1.6 \%)$ & $17(2.6 \%)$ & $39(6.7 \%)$ & $76(12 \%)$ & $<0.001$ \\
\hline
\end{tabular}

$p$-value for $A * B$ for Incident Hypertension 0.159, for rest all pairwise comparisons $p<0.001$ 
medRxiv preprint doi: https://doi.org/10.1101/2021.06.11.21258759; this version posted June 16, 2021. The copyright holder for this preprint (which was not certified by peer review) is the author/funder, who has granted medRxiv a license to display the preprint in perpetuity.

All rights reserved. No reuse allowed without permission.

Figure 1: Trajectory of BP classification from 2017 to 2019

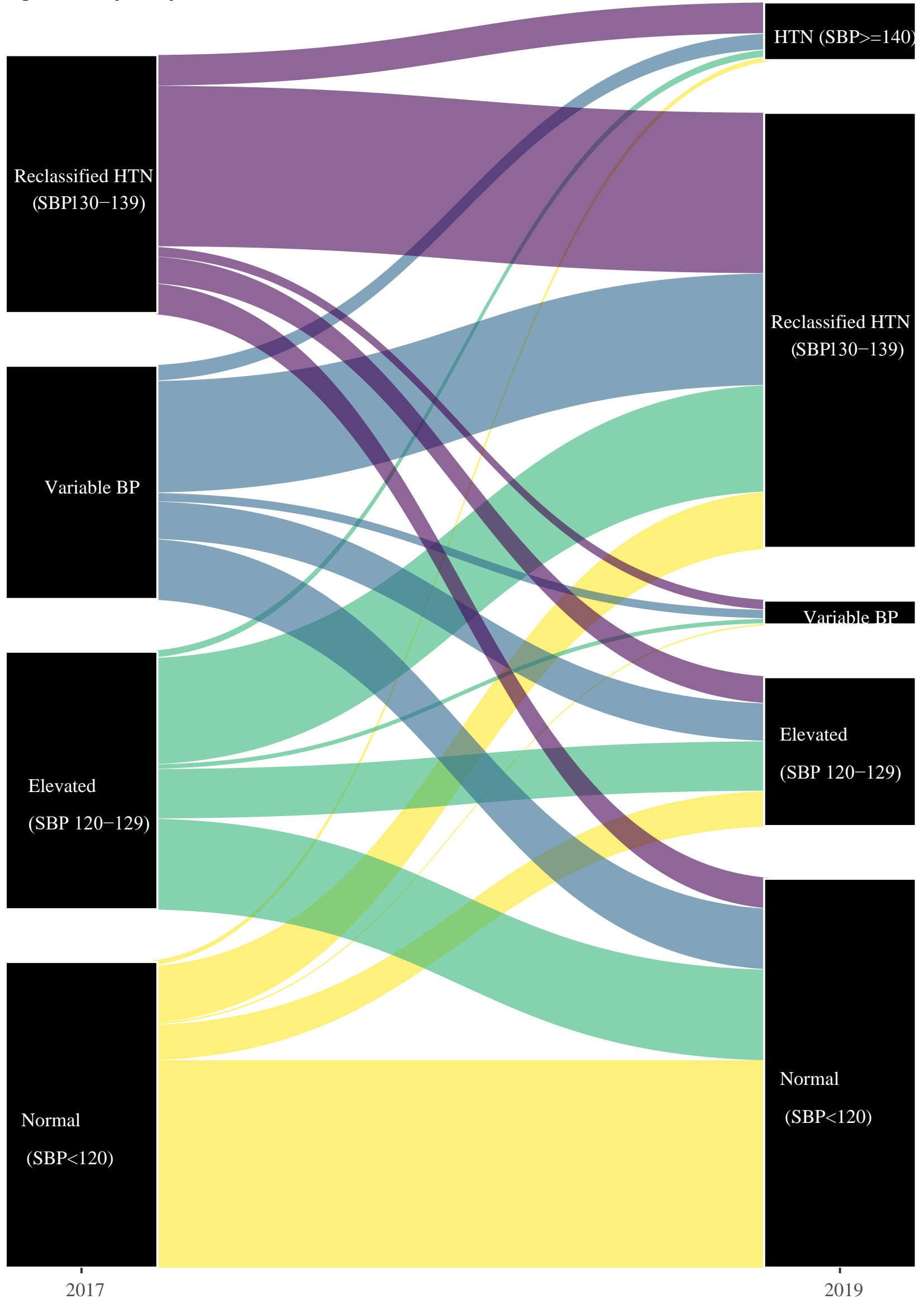


medRxiv preprint doi: https://doi.org/10.1101/2021.06.11.21258759; this version posted June 16, 2021. The copyright holder for this preprint (which was not certified by peer review) is the author/funder, who has granted medRxiv a license to display the preprint in perpetuity.

All rights reserved. No reuse allowed without permission.

Figure 2: Blood-pressure categories and hypertension classification thresholds

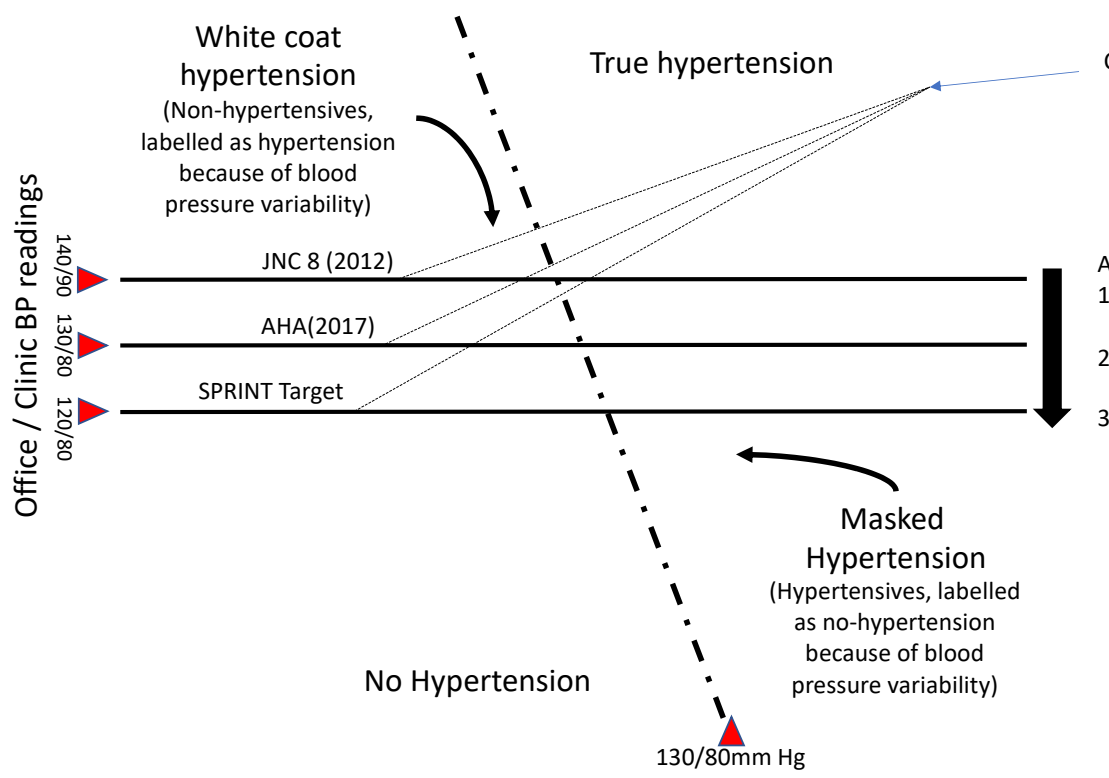

Awareness Limit

Current awareness level is $50 \%$. Only those above this line are aware about their elevated Blood pressures. (Separate lines for each diagnostic criteria)

24-hr Average blood pressure (Reference Standard)

(or True blood-pressure) 